\title{
INFORMATION TECHNOLOGIES AND PERSPECTIVES FOR EDUCATION DEVELOPMENT: LIFELONG AND ONLINE LEARNING
}

\author{
Slavka Drašković, \\ Ninela Kordić, \\ Jelena Stanković \\ Singidunum University, \\ 32 Danijelova Street, Belgrade, Serbia
}

\begin{abstract}
:
This paper analyses the perspectives of education in the context of globalization and digital technologies. The Internet and the new economy which supports the increasing need for innovation and diversity have mostly led to the demand for lifelong education in order to effectively follow and adapt to changes. Information technologies (IT) actively support the creation and development of the knowledge market, enabling access to different sources of knowledge and information. Digital technology represents one of the key factors of the new economy based on the constant need for accessing new knowledge, but it also creates a global platform for distance learning as the source of fulfilling such needs. It has also led to new approaches in education by moving the emphasis from education of young people to education of adults and developing new field in adult education: the heutagogy.

In addition, the authors analyze the relation between the innovation-success paradigm and lifelong learning, stating that the need for continuous education creates a setting in which personal development never stops. They introduce the success scheme showing that continuing education, innovation and personal development are the required conditions for success. The perspectives of online education are also implied.
\end{abstract}

Key words:

the Internet, digital technology, lifelong learning, distance learning, innovation, education, success.

\section{INTRODUCTION}

Information technologies (IT) have brought about crucial changes in all aspects of society, business and education. Years ago, IT was distinguished as one of the main drivers of knowledge sharing and lifelong learning process development (Harasim et al., 1995). The trend of rapid changes which accompanies new technology development shapes all together the present and future education processes, as well as the processes of teaching and learning. The new technology development has enabled flourishing of e-learning systems as forms of education mainly created for the purposes of exceeding some important obstacles in learning and teaching, such as scarce and restrictive resources as time, space, and finances. Over the past twenty years, people have managed to improve the quality of higher education by introducing computer-based learning systems. Such systems have the ability to create three important humane conditions for the users: communication, interaction and collaboration (Harasim et al., 1995),

which proved to be crucial for achieving the effective education outcomes..
Correspondence:

Slavka Drašković

e-mail:

sdraskovic@singidunum.ac.rs 
The absence of one of the mentioned humane actions may result in creating intellectual property inadequate to serve as a source of potential competitive advantage.

In contemporary high-tech environment, the development and competitiveness requests innovation and diversity, based on knowledge and possibilities for continuous learning (Draskovic, 2011e). In such an environment, information and knowledge become key sources for building diversity (Al-Shammari, 2011), while innovations become the new paradigm of business development (Powell and Snellman 2004), thus making the processes of learning and searching for new knowledge never ending.

\section{INFORMATION TECHNOLOGIES AND LIFELONG LEARNING}

Lifelong education is defined as the activity of learning during the lifetime with the purpose of improving knowledge, skills and competencies for personal, civil, social and/or social perspectives of employment (Commission of the European Communities, 2001). The lifelong learning concept has become particularly important over the last decade, supported by development of new technologies which have started to change the way of sending and receiving information, cooperating, socializing and communicating (Kolb, 1984).

New technologies, hypercompetition, demand for innovation and new knowledge, have led to moving an emphasis from education of young people to education of adults. Furthermore, it has contributed to flourishing of Lifelong learning (LLL) and academic programs for adults (Draskovic, 2011e). Professional education of adults has been fast-developing during the past thirty years but not in the traditional form. A lot of educational institutions have introduced distance learning systems (DLS) implementing technological innovations to this fastest growing market of higher education: adult education (Merriam and Caffarela, 1999).

The shift from the society with an emphasis on young people to the society oriented towards adults plays a significant role in higher education development, especially in cases of creating online teaching and learning programs. As the focus of higher education moved from education during young age to permanent lifelong education of adults, education itself is no longer an exclusive right of the 18-year-olds. It has become an opportunity of the middle-agers.

One of the results of such a trend in education is the development of new fields in adult education: the heutagogy. Heutagogy is a term created by Hase and Kenyon
(2001) to define a lifelong learning, approach also called self-determined learning. It is based on the idea that the student is in the center of self-learning process, not the teacher and/or the curriculum. The student creates the learning program which is personalized according to time and learning outcomes. Hase and Kenyon (2001) argue that education, especially higher education, needs to develop a system that is proactive for learners, rather than reactive. After the presentation in 2001, this concept has been treated as a practical suggestion in e-learning education environments (Chapnick and Meloy 2005).

\section{LIFELONG EDUCATION AND PERSONAL DEVELOPMENT}

Emerging of web 2.0 supported the development of lifelong learning process, enabling direct, personalized learning to be established on an everyday basis (Dunlap and Lowenthal, 2011). In this way, new technology supports development of self-determined learning putting individual needs at the center of their education. This is even more important because the need for lifelong education creates a setting in which personal-development never ceases.

Continuous personal development becomes a necessity in today's global world, which has always been for any individual striving for success. This is even more true because personal development is the result of any individual success and is part of the process of change. Personal development-personal change and success are inevitably linked as described by „The scheme of success" (Draskovic, 2011d).

The Ssheme shows that success implies changes, crises, action, pioneer undertaking-innovation of some kind, and is influenced by the circumstances, as well as by the person itself. One has to go through personal development in order to get to the next level of success, as only then the success will be accomplished (Draskovic, 2011d).

The American myth of success, on which the American nation has been built, affirms this process. It is still an inevitable part of American culture and still prevailing, but it has changed over time. In the contemporary version of the Myth, the success does not only mean „grow rich“but "develop full personal potential“, and wealth and richness will come as a result of it, as shown in Figure 2.

Thus, personal development becomes part of today's paradigm of innovation and knowledge-based society in which individual development through continuous education is the basis for development of the society (local community, company, etc.). 


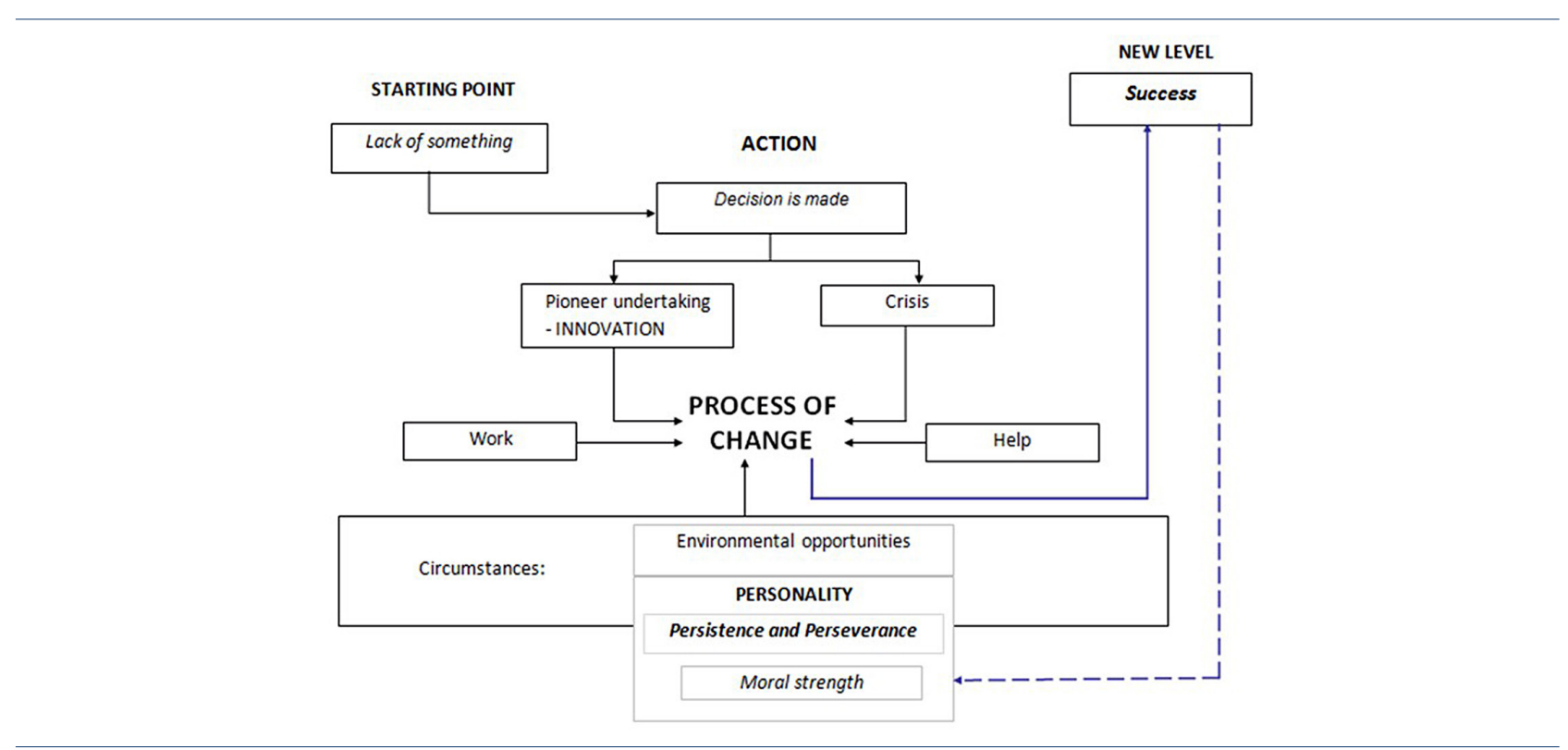

Fig. 1. The scheme of success (Draskovic, 2011.d)

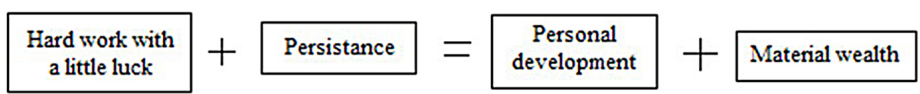

Fig. 2. American myth of success - contemporary version (Draskovic, 2011d)

Distance learning, as an innovative approach to education, teaching and learning, erases the boundaries for getting new knowledge on a continuous basis, as the source of competitiveness and development of a society.

\section{PERSPECTIVES OF ONLINE AND LIFELONG EDUCATION}

\section{Online versus traditional education}

In the beginning of distance education research and development, during last decade of the 20th century and the first decade of the 21 st century, the prevalent issue was focused on comparing traditional versus distance education, and measuring the ratio of performance of online learning against traditional education (Schulte, 2010). A number of researches have been done in order to examine the efficiency of online and distance learning courses. The researches which compared distance learning and traditional courses have shown that the distance learning methods are as efficient as the traditional whenever there is interaction among students and feedback from the lecturers (Moore and Thompson, 1990; Verduin and Clark, 1991). Successful online learning practices are basically the same as successful traditional learning practices (Moore and Thompson, 1990; Wilson and Al- len, 2010). The researches have also shown that online education requires extensive preparation and planning, and that the students are better off when their lecturers are skilled, when they adequately handle the technology, making an eye contact with the camera, repeating questions and having a sense of humor (Arsham, 2002; Wilson and Allen, 2010). It has become evident by now that the students who have taken online courses request support and instructions in order to study successfully. The support can be a combination of student-student and student-lecturer communication.

Although students performed better in an online education situation than in face-to-face situations on average, the traditional courses are more respectable (Arsham, 2002). It is considered that traditional lecturers use more obvious, clearer signals coming from their students during classes in order to make a better understanding of their teaching curricula (Ross, 2008). However, new technologies have supported the use of appropriate media and its combination during classes, with the use of auditive and visual effects which made possible to work in virtual classrooms, making the education process as vivid as in traditional, physical space. Virtual classrooms are proved to be motivating, enabling students and lecturers to actively communicate, providing 
feedback, encouraging discussions, work in small teams during and after classes. Students keep interacting with each other, which leads them to group problem solving (Moore and Thompson, 1990; Wilson and Allen, 2010).

\section{Future society based on knowledge}

In July 2004, the European Union (EU) delivered the conclusions that the improvements of LLL are necessary for successful development of „the society based on knowledge“. From 2007 to 2013 the EU bodies designed The Lifelong Learning Program (LLP) ,to enable people, at any stage of their life, to take part in stimulating learning experiences, as well as developing education and training across Europe"with the budget of almost $€ 7$ billion. The EU continued with developing LLP under the new name Erasmus in the period from 2014 to 2020 (EU Life Long Learning Programme). The goal of the program is building the society based on knowledge and enhancing lifelong learning with the support of information technologies.

Serbia joined the EU Program for lifelong learning in December 2011 following the signing of a memorandum between Serbian government and the EU. Universities in Serbia took the leading role in developing lifelong learning (EU Life Long Learning Programme). The Center for Lifelong Learning was formed at the University of Belgrade, followed by the centers at University of Novi Sad and Nis, with the help of Tempus program.

The EU countries, and less developed countries in Europe like Serbia, focus their programs and funds on sustainable lifelong education (EU Life Long Learning Programme). In the USA, the number of lifelong programs, platforms and models are in progress, especially one of the options for development of online studies so called "mass open online courses"(MOOC) (Elaine and Seaman, 2013). Among the famous MOOC platforms there are EdX, Udacity and Coursera. Reports on the number of American universities which look upon online education as a key component of their 10-year long-term strategies (precisely from 2002 to 2012) have shown a small but steady increase over time. The percentage of all the students taking at least one online course is 32, and is the highest recorded (Elaine and Seaman, 2013).

\section{Research and Predictions}

Distance education is growing exponentially, and will continue to grow (Schulte, 2010). The researchers who have analyzed the literature on trends and issues facing distance education, like Howell, Laws, Williams and Lind- say, have concluded that the technology will tend towards omnipresent and versatile Internet technology and that IT fluency will be needed and expected by all educational users (Eastmond, 2007). They also predict that the demand for online distance education will increase, and that the distinction between it and conventional education will blur. Winston agrees with that and underlines forces that will drive higher education with digitization, among which are digital publications, digital libraries, student proficiency in digital communication, publisher control of content and curriculum, increasing power of consumerdriven education delivery, increase in for-profit colleges and universities, etc. (Eastmond, 2007). He argues that these forces will create a number of possible scenarios by 2030 , in which he describes the academe in a new age. The emerging generation will embrace and become natural users of the omnipresent Internet technologies. He believes that they will need to continuously learn, at any time or place. Winston further foresees that the publishing industry will own the knowledge base, transmitting it digitally, replacing the classroom professors as the source of knowledge. Professors, not higher education institutions, will be accredited and they will be free agents, working for several institutions simultaneously. He also foresees professional association accreditation and flourishing for-profit universities (Eastmond, 2007). Other researchers, like Beaudion (2006), have made similar conclusions but argue that despite the rapid development of online education over the past decade, the changes are being implemented at a slow pace. He predicts further globalization, the expansion of online LLL process, but also considers that the conventional higher education will not take advantage of digital media and telecommunication. The vacuum will be filled with further inclusion of commercial companies, foreign institutions and for-profit universities in the process. His speculations about further online education development are directed towards gaining interactive and collaborative advantages of DLS over traditional education in classrooms, followed by strong development of high technologies, which will enable people to connect with technology to create half-machines or cyborgs (Beaudoin, 2006).

Several prominent university higher education and new technologies experts (Parr, 2014) have given their predictions about the future of higher education. They have identified augmented reality, sensor technology and crowd sourcing as the technologies that could revolutionize higher education. They consider such trends as revolutionary for the higher education, and believe that they should be used in many different aspects of education over the next few years. 


\section{CONCLUSIONS}

The introduction of new technologies has helped eliminating space barriers in teaching and learning. Furthermore, it has contributed to adult education development in the sense of learning from home, after work, from whatever source, wherever it comes from.

Online learning will continue to grow as distance learning has become: (1) an opportunity for collecting fresh knowledge, (2) a response to global trends and challenges such as hypercompetition, (3) a response to the need for better education approaches in time of constant change and innovation, (4) the part of new development paradigm based on knowledge without borders, (5) a solution for eliminating financial limits in education, and (6) an answer to the need for implementation of new technologies in all aspects of life and work (Draskovic, 2011e). Therefore, LLL and online education have become the vital part of a new paradigm of innovation, knowledgebased society and personal development.

\section{REFERENCES}

Al-Shammari, M. (2011). Customer-Centric Knowledge Management: Concepts and Applications. Hershey: IGI Global.

Arsham, H. (2002). Impact of the Internet on Learning and Teaching. USDLA Journal. 16 (3), 9-21.

Beaudoin, M. (2006). Perspectives on Higher Education in the Digital Age. In M.F. Beaudoin (Ed.), Perspectives on Higher Education in the Digital Age, (pp. 1-20). New York: Nova Science Publishers, Inc.

Chapnick S., \& J. Meloy (2005). From Andragogy to Heutagogy. In Chapnick S \& J. Meloy (Ed), Renaissance elearning: creating dramatic and unconventional learning experiences. (pp. 36-37) San Francisco: Pfeiffer.

Commission of the European Communities. (2001). Making a European Area of Lifelong Learning a Reality. Retrieved February 02, 2016. from http://eur-lex.europa.eu/LexUriServ/LexUriServ. do?uri=COM:2001:0678:FIN:EN:PDF

Drašković, S. (2011). Ključ uspeha: put ka ličnom napredovanju i uspehu. Beograd: Zadužbina Andrejević

Drašković, S. (2011). Učenje na daljinu kao deo nove paradigme privrede i društva. In Digitalizacija kulturne i naučne baštine, univerzitetski repozitorijumi i učenje na daljinu, 30.09-02.10.2011 (pp.107-109) Belgrade: University of Belgrade, Faculty of Philology.
Dunlap, J. C., \& P. R. Lowenthal. (2011). Learning, unlearning, and relearning: Using Web 2.0 technologies to support the development of lifelong learning skills. In G. D. Magoulas (Ed.), E-infrastructures and technologies for lifelong learning: Next generation environments. Hershey, PA: IGI Global

Eastmond, D. (2007). Perspectives on Higher Education in the Digital Age by Michael F. Beaudoin. The Quarterly Review of Distance Education, 8(2), 175-180.

Elaine A.I., \& Seaman, J. (2013). Changing Course: Ten Years of Tracking Online Education in the United States, Babson Survey Research Group Retrieved January 21, 2016. from http://www.onlinelearningsurvey.com/reports/changingcourse.pdf

EU Life Long Learning Programme (2009). Retrieved February 02, 2016. from http://ec.europa.eu/education/tools/llp_en.htm and http://eur-lex.europa.eu/ legal-content/EN/TXT/?uri=URISERV:ef0016

Harasim, L., Hiltz, S. R., Teles, L., \& Turoff, M. (1995). Learning Networks, A Field Guide to Teaching and Learning Online. Cambridge MA: The MIT Press.

Hase, S., \& Kenyon, C. (2001). From Andragogy to Heutagogy. Southern Cross Universitypublication. Retrieved January 06, 2016. From http://www.psy.gla. ac.uk/ steve/pr/Heutagogy.html\#beyond

Kolb, D. A. (1984). Experiential learning: Experience as the source of learning and development. New Jersey: Prentice-Hall. Retrieved March 02, 2016. from: http://academic.regis.edu/ed205/kolb.pdf

Merriam, S. B., \& Caffarela, R. S. (1999). Learning in adulthood: A comprehensive guide (2nd ed.). San Francisco,CA: Jossey-Bass

Moore, M. G., \& Thompson, M. M. (1990). The effects of distance learning: A summary of the literature. Research Monograph No. 2. Pennsylvania: The Pennsylvania State University, American Center for the Study of Distance Education.

Parr, C. (2014).The future of higher education? Five experts give their predictions. Times Higher Education. Retrieved March 15, 2016 from https:// www.timeshighereducation.com/the-future-ofhigher-education-five-experts-give-their-predictions/2011867.article.

Powell W.W., \& Snellman, K. (2004). Annu. Rev. Sociol. 30. 199-220. Downloaded from arjournals.annualreviews.org by Stanford Univ. Robert Crown law Lib. doi: 10.1146/annurev.soc.29.010202.100037. Retrieved January 21, 2106. from http://scholar. harvard.edu/files/kaisa/files/powell_snellman.pdf

Ross, W. (2008). Mentoring and Tutoring Online Learners: Personal Reflections: National Implications. National FORUM Journals. 2 (1). 1-5. 
Schulte, M. (2010). University Instructors Perceptions of Factors in Distance Education Transactions. Online Journal of Distance Learning Administration. 13(2) Retrieved February 02, 2016. from http:// www.westga.edu/ distance/ojdla/summer132/ schulte132.html

Verduin, J. R., \& Clark, T. A. (1991). Distance education: The foundations of effective practice. San Francisco, CA: Jossey-Bass Publishers.
Wilson, D., \& Allen, D. (2010). Success rates of online versus traditional college students. Higher Education Journal Retrieved February 02, 2016. from http://www.aabri.com/manuscripts/11761.pdf 